\title{
Original Research \\ Designation of Chosen Heavy Metals in Used Engine Oils Using the XRF Method
}

\author{
Grzegorz Zając ${ }^{1 *}$, Joanna Szyszlak-Bargłowicz' ${ }^{1}$ Tomasz Słowik ${ }^{1}$, \\ Andrzej Kuranc', Agnieszka Kamińska² \\ ${ }^{1}$ Department of Power Engineering and Transportation, Faculty of Production Engineering \\ ${ }^{2}$ Department of Applied Mathematics and Computer Science, Faculty of Production Engineering \\ University of Life Sciences in Lublin, Głęboka 28, 20-612 Lublin, Poland \\ Received: December 29, 2014 \\ Accepted: July 9, 2015
}

\begin{abstract}
Taking into consideration the fact that used oils are considered hazardous and extremely toxic, their subsequent use creates a real threat to the environment. The only effective measure for protecting the natural environment from used oil contamination is collection and controlled utilization. Only appropriate used oil management can guarantee minimal environmental contamination and prevent its irreversible degradation.

The aim of our study was to determine the content of select heavy metal elements in used engine oils originating from agricultural tractors and agricultural machines of varying mileage. The tests were carried out by using the HD XRF method. The researched samples showed a high content of zinc remaining at 726$1,389 \mathrm{mg} \cdot \mathrm{kg}^{-1}$. The contents of molybdenum, iron, and copper also were high, at Mo 360-689 $\mathrm{mg} \cdot \mathrm{kg}^{-1}, \mathrm{Fe} 16.5-$ $267 \mathrm{mg} \cdot \mathrm{kg}^{-1}$, and $\mathrm{Cu} 4.63-76.87 \mathrm{mg} \cdot \mathrm{kg}^{-1}$. Low nickel, manganese, chromium, and lead contents were found in the ranges: Ni 0.14-0.75 $\mathrm{mg} \cdot \mathrm{kg}^{-1}, \mathrm{Mn} 0.41-4.27 \mathrm{mg} \cdot \mathrm{kg}^{-1}, \mathrm{Cr} 0.36-10.66 \mathrm{mg} \cdot \mathrm{kg}^{-1}$, and $\mathrm{Pb} 0.9-13.71 \mathrm{mg} \cdot \mathrm{kg}^{-1}$. Mercury and cadmium were not found in the tested oils.
\end{abstract}

Keywords: used engine oils, heavy metals, lubricating oil analysis

\section{Introduction}

In recent years the problem of the contamination of soil and water with petroleum products has become ever more increasing $[1,2]$. Such products mainly contain aliphatic and aromatic hydrocarbons, but also - generally in small quantities - heavy metal ions such as lead, tin, arsenic, mercury, germanium, antimony, thallium, vanadium, and iron. Used engine oils are particularly dangerous for the environment due to their contamination with products of thermal decomposition and mechanical impurities. The above products become hardly biodegradable and have carcinogenic properties, therefore, information on the content of trace elements in these products are crucial, taking into account the environmental aspect.

*e-mail: grzegorz.zajac@up.lublin.pl
The chemical composition of used oil depends on the type of the base oil, the applied refining additives, physicochemical conversion that the oil underwent in the course of operation, as well as from any possible impurities occurring during the collection and storage of the used oils [3].

Metals occurring in used oils originate from various sources. For the main part, these are the products of corrosion and wear of mating metal surfaces and functional additives. The content of metals in European used oils amounts to approximately $0.7 \%(\mathrm{~m} / \mathrm{m})[3,4]$.

It is estimated that in European countries, where consumption of lubricating greases amounts to 4.5 million $\mathrm{Mg}$, approximately $600,000 \mathrm{Mg}$ permeates soil or groundwater. In Poland, from 300 to 350 thousand $\mathrm{Mg}$ of fresh oils are annually put on the market, with engine oils constituting over $50 \%$ of that amount. Used oils constitute about $60 \%$ of the initial mass, which makes up from 180 to 210 thousand 
$\mathrm{Mg}$ of hazardous waste every year. It is estimated that the current level of used oils management equals approx. $60 \%$ (over $50 \%$ of which is directed for re-refining, about $20 \%$ for recycling, and the rest for warehousing); the remaining $40 \%$ of used oils remains outside the collection system [5].

A significant dispersion of oils connected with a large number of users, who use the oils only in small quantities, poses a serious environmentally relevant problem. Such oil is replaced by new oil after the expenditure of a certain amount of mileage or passage of time. The disposal procedure concerning the changed oils varies. In the case of passenger cars, the change of oil usually takes place at service facilities where used oil is collected by companies servicing the cars. Ever more frequently the charge for the engine oil and oil filter replacement is included in the product price, which encourages users to change oil at such service points. However, the situation is different when it comes to tractors and agricultural machines, where oil service is performed on the spot, in the agricultural holding or farm, and usually the used oil remains there and is reused by the farmers for other purposes. Taking into consideration the fact that used oils are considered to be hazardous and extremely toxic waste, their subsequent use creates a real threat to the environment.

The aim of our study was to determine the content of select heavy metals $(\mathrm{Cd}, \mathrm{Pb}, \mathrm{Hg}, \mathrm{Cr}, \mathrm{Sn}, \mathrm{Zn}, \mathrm{Cu}, \mathrm{Ni}, \mathrm{Fe}$, $\mathrm{Mn}, \mathrm{Mo}$ ) in used engine oils originating from agricultural tractors and machines of varying mileage. Used engine oils should be managed in compliance with legal provisions; if not, they can pose a serious threat to the environment. Therefore, it is of utmost importance to specify and estimate the risk that such actions can involve.

\section{Material and Methods}

Twenty samples of used engine oils from agricultural tractors and machines by different manufacturers available on the market were analyzed. The samples were collected during oil replacement upon varying mileage. These were obtained from service companies dealing with agricultural tractor maintenance, as well as from individual farmers within the Lubelskie Voivodeship.

The collected oil samples were divided according to the mileage of the tractors and the machines: A1-8 are oils from tractors of low mileage (up to 300 work hours), B1-8 are oils from tractors of medium mileage (300-900 h), and C14 are oils from tractors of high mileage (more than $900 \mathrm{~h}$ ).

The research was carried out using of the HD Maxine analyser by XOS, a multi-element analyser that determines trace elements in liquid samples in hydrocarbon matrices using high definition x-ray fluorescence (HDXRF). The device enables simultaneous determination of $\mathrm{Cd}, \mathrm{Pb}$, $\mathrm{Hg}, \mathrm{Cr}, \mathrm{Sn}, \mathrm{Zn}, \mathrm{Cu}, \mathrm{Ni}, \mathrm{Fe}, \mathrm{Mn}$, and Mo contents within ranges corresponding to the concentrations of these elements occurring in engine oils. The device's configuration is intended for the petroleum industry.

Since the device does not require any sample preparation, the sample was dosed directly into the sample cups.
The analysis was carried out in three repetitions for each sample.

The results obtained were subject to statistical analysis with the use of STATISTICA. Data mining methods were used, while the non-parametric Kruskal-Wallis one-way analysis of variance was used to test the impact of tractor engine mileage on the content of heavy metals in used engine oils.

\section{Results and Discussion}

The results of surveys conducted in companies dealing with agricultural tractor servicing show that hardly $15 \%$ of used oils from the agricultural sector is collected by service facilities and managed in line with applicable provision of the law. The remaining part stays directly at the farm. The surveys carried out among the farmers from Lubelskie Voivodeship show that used engine oil is utilized for the maintenance of agricultural machines or wood (35\%), reutilized as lubricating grease (i.e., for the lubrication of chain saws, or older tractors; $60 \%$ ), for space heating $(12 \%)$, and stored on the farm for other purposes $(3 \%)$.

None of the above-mentioned methods of used oil management is in compliance with the relevant legal regulations [4]. Moreover, such management poses a potential environmental threat [6]. The utilization of used oil as a preservative agent for wood or machine causes its permeation into the soil as a result of, for instance, washing off through precipitation. Reutilized oils also pose a serious threat to the environment. Reutilization usually means using the oil in agricultural tractors with a high level of operational wear, which entails leakage and permeation into the soil during operation or when parked. Utilization of used oils for lubricating chain saws is equally reprehensible. Used oil combustion, if carried out in controlled conditions, is not dangerous to the environment. However, in agricultural holdings it is combusted by adding to fine coal, or combusted in agriculturally prepared burners. Such conduct causes the creation of post-combustion toxic wastes and emissions of heavy metals into the atmosphere [7-9].

Heavy metals in soil consist of the source of the threat to plants and underground water, and in consequence these can become incorporated into the food chain. Furthermore, heavy metals that contaminate the soil impede the development of microorganisms functioning therein, which leads to the disturbance of basic physiological functions, and above all processes connected with decomposition and transformation of organic matter $[10,11]$.

The results of the designation of particular heavy metal elements in used engine oils are shown in Table 1. The obtained data indicate that the content of individual metal was quite diversified with respect to the type of machine, the type of oil, and mileage. Fig. 1 presents the distribution of characteristics, the mean, the outliers, and the extremes.

The majority of analytical methods of designating heavy metals in lubricating oils that are described in literature are based on atomic spectrometry techniques such as: 
Table 1. Results of analysis of trace metals in oil using XRF.

\begin{tabular}{|c|c|c|c|c|c|c|c|c|c|c|c|}
\hline \multirow{2}{*}{$\begin{array}{l}\text { Sample } \\
\text { ID }\end{array}$} & \multicolumn{11}{|c|}{ Metal concentrations $\left[\mathrm{mg} \cdot \mathrm{kg}^{-1}\right]$} \\
\hline & $\mathrm{Zn}$ & Mo & $\mathrm{Fe}$ & $\mathrm{Cu}$ & $\mathrm{Pb}$ & $\mathrm{Cr}$ & $\mathrm{Mn}$ & $\mathrm{Ni}$ & $\mathrm{Sn}$ & $\mathrm{Cd}$ & $\mathrm{Hg}$ \\
\hline A1 & 1,269 & 378 & 36.23 & 27.83 & 2.24 & 0.92 & 1.76 & 0.28 & n.d. & n.d. & n.d. \\
\hline A2 & 1,106 & 383 & 18.25 & 25.35 & 4.02 & 0.51 & 3.34 & 0.14 & n.d. & n.d. & n.d. \\
\hline A3 & 1,001 & 608 & 16.5 & 10.45 & 3.74 & 0.53 & 2.05 & 0.20 & n.d. & n.d. & n.d. \\
\hline A4 & 726 & 472 & 112 & 14.96 & 4.33 & 1.47 & 4.27 & 0.23 & 60.78 & n.d. & n.d. \\
\hline A5 & 1,104 & 372 & 19.03 & 7.04 & 2.29 & 0.36 & 0.41 & 0.18 & n.d. & n.d. & n.d. \\
\hline A6 & 986 & 689 & 23.51 & 76.87 & 5.31 & 0.77 & 2.38 & 0.57 & n.d. & n.d. & n.d. \\
\hline A7 & 935 & 655 & 19.57 & 13.34 & 5.8 & 0.66 & 2.11 & 0.69 & n.d. & n.d. & n.d. \\
\hline A 8 & 1,079 & 606 & 25.5 & 7.53 & 1.33 & 0.53 & 0.53 & 0.61 & 59.92 & n.d. & n.d. \\
\hline B1 & 1,165 & 443 & 33.51 & 6.23 & 1.46 & 0.59 & 1.34 & 0.50 & n.d. & n.d. & n.d. \\
\hline B2 & 1,070 & 371 & 44.22 & 23.46 & 6.92 & 0.59 & 1.34 & 0.41 & 107 & n.d. & n.d. \\
\hline B3 & 1,216 & 431 & 41.19 & 6.78 & 0.90 & 0.73 & 0.57 & 0.45 & n.d. & n.d. & n.d. \\
\hline B4 & 1,140 & 616 & 47.35 & 43.88 & 4.78 & 0.53 & 2.17 & 0.60 & n.d. & n.d. & n.d. \\
\hline B5 & 1,374 & 402 & 24.25 & 4.63 & 1.06 & 0.58 & 0.65 & 0.25 & n.d. & n.d. & n.d. \\
\hline B6 & 1,200 & 449 & 19.45 & 20.34 & 2.30 & 0.62 & 2.76 & 0.24 & n.d. & n.d. & n.d. \\
\hline B7 & 1,106 & 383 & 18.25 & 25.35 & 4,02 & 0.51 & 3.34 & 0.14 & n.d. & n.d. & n.d. \\
\hline B8 & 1,221 & 403 & 51.73 & 15.03 & 1.84 & 1.16 & 1.14 & 0.27 & n.d. & n.d. & n.d. \\
\hline $\mathrm{C} 1$ & 1,389 & 360 & 144.33 & 7.51 & 2.61 & 10.66 & 1.29 & 0.54 & n.d. & n.d. & n.d. \\
\hline $\mathrm{C} 2$ & 1,017 & 425 & 39.24 & 5.96 & 1.87 & 0.59 & 0.65 & 0.32 & n.d. & n.d. & n.d. \\
\hline $\mathrm{C} 3$ & 1,144 & 388 & 69.58 & 5.85 & 1.42 & 2.91 & 1.51 & 0.32 & n.d. & n.d. & n.d. \\
\hline $\mathrm{C} 4$ & 887 & 425 & 267 & 11.75 & 13.71 & 3.47 & 2.19 & 0.75 & n.d. & n.d. & n.d. \\
\hline Mean & $1,106.7$ & 462.95 & 53.53 & 18.00 & 3.59 & 1.43 & 1.79 & 0.38 & & & \\
\hline S.D. & 158.22 & 107.05 & 60.08 & 17.14 & 2.93 & 2.31 & 1.06 & 0.19 & & & \\
\hline Median & 1,106 & 425 & 34.87 & 12.54 & 2.45 & 0.60 & 1.63 & 0.32 & & & \\
\hline Min & 726 & 360 & 16.5 & 4.63 & 0.90 & 0.36 & 0.41 & 0.14 & & & \\
\hline Max & 1,389 & 689 & 267 & 76.87 & 13.71 & 10.66 & 4.27 & 0.75 & & & \\
\hline C.V. & $14.3 \%$ & $23.1 \%$ & $112.2 \%$ & $95.2 \%$ & $81.6 \%$ & $161.6 \%$ & $59.4 \%$ & $49.6 \%$ & & & \\
\hline
\end{tabular}

n.d. - not detected

F-AAS, ET-AAS, DC-OES, ICP-OES, ICP-MS, and AFS [12-15]. However, the methods require special sample preparation, which are usually laborious [15]. An attractive alternative to those mentioned above is $\mathrm{X}$-ray fluorescence (XRF), which does not require complicated sample preparation [16-20]. Pouzar et al. proved that there is no statistically important difference between the results of XRF and ICP-OES [17]. Similar conclusions were formulated by Sagi [18] and Yang et al. [20], who compared XRF and ICP-AES, and by Simbolon [19], who compared XRF and AAS methods.

The quantity designation of heavy metals in used lubricating oils can be used for a quality control of oils and engine diagnosis. Less often it can be used for assessment of wasted oil environment influence [13]. Therefore, accessible literature concerns mostly such elements as $\mathrm{Zn}, \mathrm{Fe}$, $\mathrm{Cu}$, and $\mathrm{Pb}$. Table 2 shows the concentration values of heavy metals under analysis presented in literature [20-23] in reference to concentration ranges obtained in our own research. Yang et al. [20] researched the presence of select heavy metals in used oils from vehicle service stations maintaining passenger cars working on petrol only by using the XRF method. Hamawand et al. [21] researched the content of select heavy metals in used engine oil from passenger cars using the AAS method. Cassap [22] analysed new and used engine oils from passenger cars using the IPC-OS method. Hamad et al. [23] analysed used oils collected from automotive repair shops using the IPC and AAS methods. 
a)

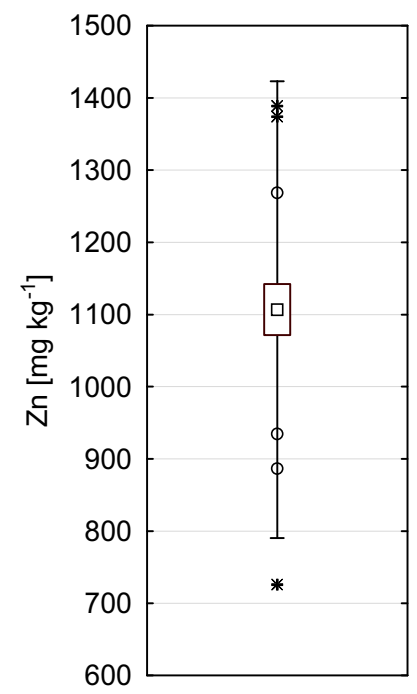

d)

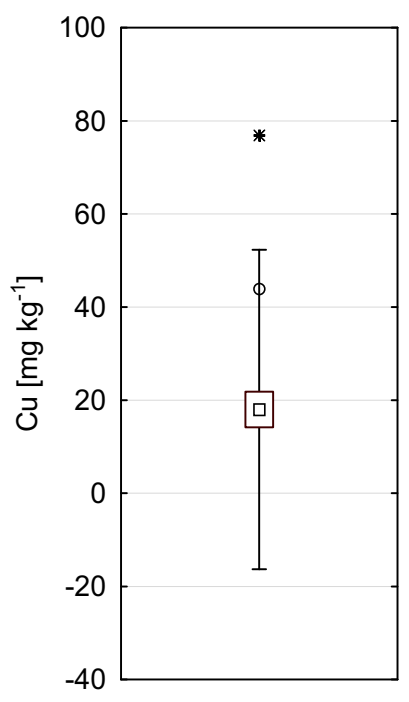

b)

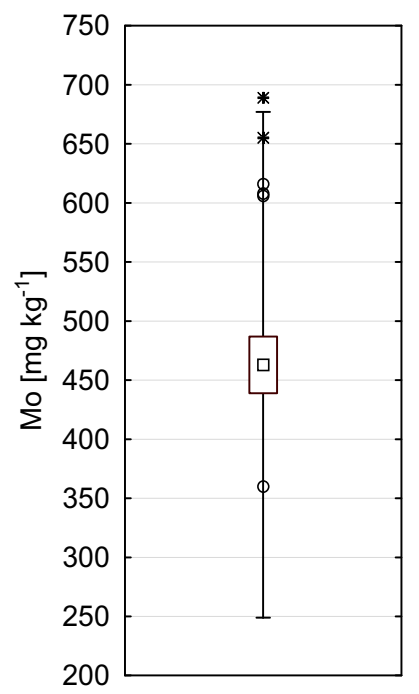

e)

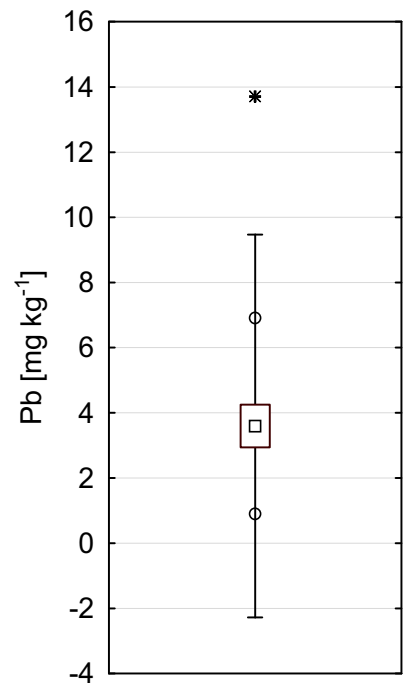

c)

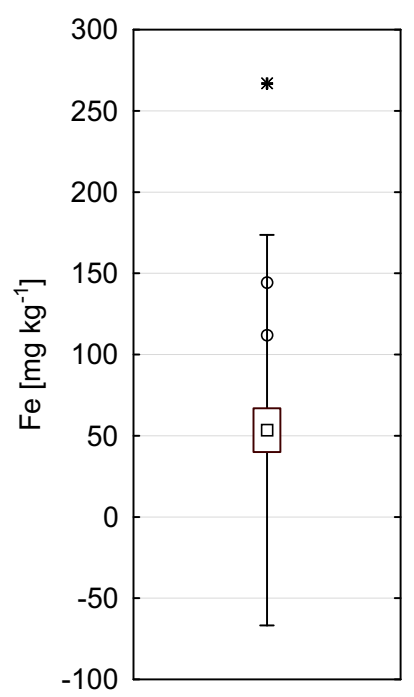

f)

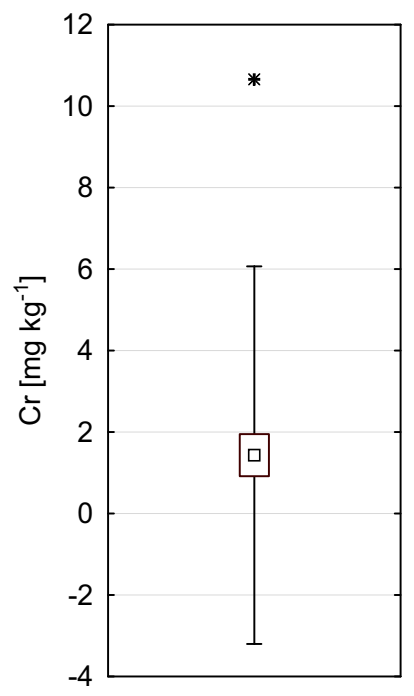

g)

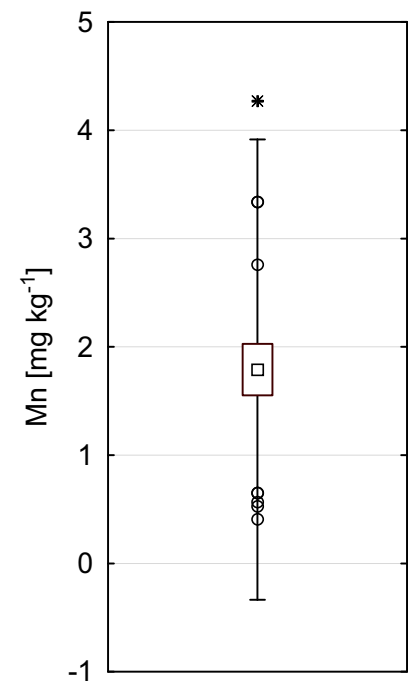

h)

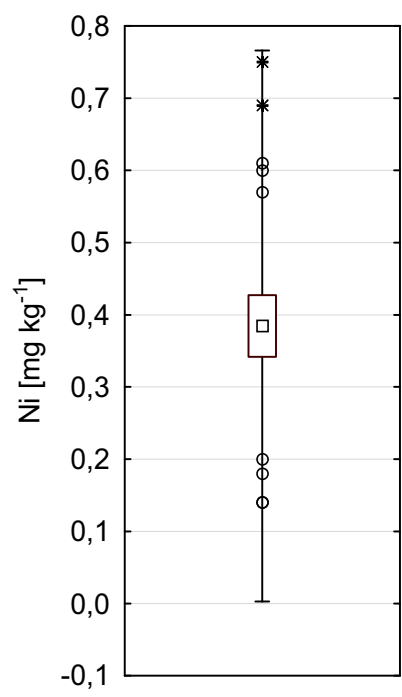

$\square$ - Mean $\square-$ Mean \pm Standard Deviation, I-Mean $\pm 2 *$ Standard Deviation, $O$ - Outlier, +- Extreme Fig. 1. Box plots for specified elements. 
Table 2. Values reported in literature $\left[\mathrm{mg} \cdot \mathrm{kg}^{-1}\right]$.

\begin{tabular}{|c|c|c|c|c|c|}
\hline \multirow{4}{*}{ Elements } & \multirow{2}{*}{$\begin{array}{l}\text { Own } \\
\text { resarch }\end{array}$} & \multicolumn{4}{|c|}{ References } \\
\hline & & [20] & [21] & {$[22]$} & [23] \\
\hline & \multicolumn{5}{|c|}{ Method } \\
\hline & HD XRF & $\mathrm{XRF}$ & AAS & ICP-OS & ICP \\
\hline $\mathrm{Zn}$ & $726-1,389$ & n.r. & 1,280 & 1,106 & 701 \\
\hline Mo & $360-689$ & n.r. & n.r. & 0.38 & 6 \\
\hline $\mathrm{Fe}$ & $16.5-267$ & 21 & 72 & 30.8 & 76 \\
\hline $\mathrm{Cu}$ & $4.63-76.87$ & 18.2 & 4.6 & 3.49 & 13 \\
\hline $\mathrm{Pb}$ & $0.9-13.71$ & 15.8 & 14.6 & 8.0 & 946 \\
\hline $\mathrm{Cr}$ & $0.36-10.6$ & n.r. & 1.5 & 2.54 & n.r. \\
\hline $\mathrm{Mn}$ & $0.41-4.27$ & n.r. & 1.5 & 0.89 & 2 \\
\hline $\mathrm{Ni}$ & $0.14-0.75$ & n.r. & n.r. & 0.48 & 1 \\
\hline $\mathrm{Cd}$ & n.d. & n.r. & 1 & 0.27 & $<1$ \\
\hline $\mathrm{Sn}$ & 59.92-107 & n.r. & 1.6 & 2.53 & 1 \\
\hline $\mathrm{Hg}$ & n.d. & n.r. & n.r. & n.r. & n.r. \\
\hline
\end{tabular}

n.d. - not detect, n.r. - not reported

Particular attention is currently being paid to environmental contamination with mercury and cadmium compounds given the anthropogenic distribution of these elements in the environment and their high toxicity. The potential threat of the contamination of the natural environment with cadmium is high, since it is subject to both anthropogenic concentration and exceptionally easy bioconcentration. Permanent control of the level of environmental pollution is necessary - in particular when it comes to food products - because this metal displays a high level of toxicity for humans and animals [24]. None of the analysed samples of the used engine oils showed the presence of cadmium. This, however, does not mean that the cadmium threat should be ruled out. Published references specify values ranging from 0.27 to $1 \mathrm{mg} \cdot \mathrm{kg}^{-1}$ (Table 2). Scientific studies found in the literature do not provide information on the content of $\mathrm{Hg}$ in new and used engine oils, although the presence of mercury in crude oil was stated [25], the analysed samples were not tested for the presence of mercury; therefore, it may be concluded that the risk posed by this metal is minimal.

Due to the global atmospheric range of lead contamination, its anthropogenic accumulation is noticed in the majority of soils. In nearly all soil the balance of lead is positive and indicates a steady increase in content. Even though these are admissible amounts when it comes to ecotoxicity and phytotoxicity, the elevated content of lead in the soil may pose a threat to human beings, and especially to children [24]. Lead is removed from base oils, hence its presence in used oils is mainly connected with bearing wear [26, 27], but the contamination source may also be fuel. This, however, pertains mainly to petrol-fuelled engines [28].
The analysed samples were collected from diesel-fuelled engines. Therefore, it can be concluded that the established content of lead is connected with the wear of engine parts. The average content of lead in the samples amounted to $3.59 \mathrm{mg} \cdot \mathrm{kg}^{-1}$. The lowest value was noted for the B3 sample $\left(0.9 \mathrm{mg} \cdot \mathrm{kg}^{-1}\right)$ and the highest for $\mathrm{C} 4\left(13.71 \mathrm{mg} \cdot \mathrm{kg}^{-1}\right)$. Such a high content of $\mathrm{Pb}$ in the $\mathrm{C} 4$ sample caused an extremely high value of variation coefficient, which exceeded $80 \%$. The range obtained in the course of the research is similar to data provided by Yang [20] (15.8 $\left.\mathrm{mg} \cdot \mathrm{kg}^{-1}\right)$, Hamawand et al. [21] (14.6 $\left.\mathrm{mg} \cdot \mathrm{kg}^{-1}\right)$, and Cassap [22] $\left(8 \mathrm{mg} \cdot \mathrm{kg}^{-1}\right)$.

Nickel compounds are classified as hazardous and carcinogenic substances. Nickel, when introduced into water reservoirs, is significantly absorbed by sediments. However, it also is subject to strong bioaccumulation, particularly in phytoplankton, which effects its fast incorporation into the food chain [24]. In used oils nickel mainly comes from the piston rings and the shaft [27]. The content of nickel found in the analysed samples ranged from 0.14 to $0.75 \mathrm{mg} \cdot \mathrm{kg}^{-1}$ (on average $0.38 \mathrm{mg} \cdot \mathrm{kg}^{-1}$ ). In half of the analysed samples the content of nickel did not exceed $0.32 \mathrm{mg} \cdot \mathrm{kg}^{-1}$. Variability in the content was characterized by a high level of differentiation, amounting to almost $50 \%$. The content of nickel in used oils stated in the literature is comparable with results obtained in the research (Table 2).

Tin is entirely removed from base oils since it is considered contamination, therefore its presence in used oil results from the wear of the shaft, bearings, guides, and sleeves [26, 27]. In the analysed oils tin was noted in three samples. The highest concentration for this element was determined for sample B2 $\left(107 \mathrm{mg} \cdot \mathrm{kg}^{-1}\right)$, and the lowest for A8 $\left(59.9 \mathrm{mg} \cdot \mathrm{kg}^{-1}\right)$. Designation of tin in only three samples indicates that its presence in oil is the result of the specific wear processes of engine parts. The values obtained in the research are much higher than those provided by Hamawand et al. [21] at $1.6 \mathrm{mg} \cdot \mathrm{kg}^{-1}$ and Cassap [22] at $2.53 \mathrm{mg} \cdot \mathrm{kg}^{-1}$.

Due to the relatively high copper bioconcentration factor and high level of its anthropogenic deployment, it poses a significant threat of local biological contamination [24]. Copper in used oils comes mainly from the wearing products of the bearings, rings, and valve guides; in smaller quantities it is introduced in the form of additives [26, 27]. The content of copper in the analysed samples ranged between $4.63-76.87 \mathrm{mg} \cdot \mathrm{kg}^{-1}$ (on average $18 \mathrm{mg} \cdot \mathrm{kg}^{-1}$ ), with a standard deviation of $17.14 \mathrm{mg} \cdot \mathrm{kg}^{-1}$. The content of $\mathrm{Cu}$ in one of the samples caused an extremely high value of variation coefficient, which exceeded $95 \%$. The data about content of copper in used oil found in the literature (Table 2) shows that it remains within the range obtained in the presented research.

Similar to copper, zinc comes mostly from anthropogenic sources [24]. It is the basic active element of hightemperature antioxidation additives. It can also be found in the composition of antiwear additives or corrosion inhibitors added to engine oils [26, 27]. The increase in the content of zinc in used oils in comparison with fresh oil may be the result of the presence of wearing products. 
A high concentration of $\mathrm{Zn}$ was found in the analysed samples, ranging from 726 to $1,389 \mathrm{mg} \cdot \mathrm{kg}^{-1}$. The average content of $\mathrm{Zn}$ in a sample equalled $1,106.7 \mathrm{mg} \cdot \mathrm{kg}^{-1}$, and the standard variation was $158.22 \mathrm{mg} \cdot \mathrm{kg}^{-1}$. In half of the analysed samples the content of zinc did not exceed $1,106 \mathrm{mg} \cdot \mathrm{kg}^{-1}$. The coefficient of variation of $\mathrm{Zn}$ in the samples was small at $14 \%$. The values obtained found its confirmation in the literary data. Hamawand et al. [21] determined $\mathrm{Zn}$ in used oils to be $1,280 \mathrm{mg} \cdot \mathrm{kg}^{-1}$. A similar value was established by Cassap [22] at $1,106 \mathrm{mg} \cdot \mathrm{kg}^{-1}$, while the lowest was obtained by Hamad et al. [23] at $701 \mathrm{mg} \cdot \mathrm{kg}^{-1}$.

Although there is no risk of global contamination of the natural environment by chromium, its local introduction into the atmosphere, water, and soil may cause excessive incorporation into biogeochemical circulation, thus posing a threat to human and animal health [24]. The presence of chromium in engine oil is usually traced to the wear of engine parts. The high level of chromium may indicate excessive wear of chromed components such as rings and sleeves [26, 27]. The content of chromium in the analysed samples ranged from 0.36 for the A5 sample to 10.66 $\mathrm{mg} \cdot \mathrm{kg}^{-1}$ for sample $\mathrm{C} 1$. The average content equalled $1.43 \mathrm{mg} \cdot \mathrm{kg}^{-1}$, whereas in half of the analysed samples the content of chromium did not exceed $0.6 \mathrm{mg} \cdot \mathrm{kg}^{-1}$. As a result of extremely high content of this element in one of the samples, the coefficient of variation amounted to as high as $161 \%$. The presented values can be confirmed by the data found in the literature (Table 2).

In general, the share of iron in the overall contamination of the environment is not specified since it does not pose a threat to the environment. However, as a most commonly used metal, it may provide information on the impact of some anthropotechnical elements on the natural environment. Iron is the most typical engine wear product present in engine oil. Therefore, its concentration in used oil mainly depends on lubricating conditions inside the engine. In the analysed samples the lowest established content of iron was $16.5 \mathrm{mg} \cdot \mathrm{kg}^{-1}$ for sample A3, and the highest was $267 \mathrm{mg} \cdot \mathrm{kg}^{-1}$ for sample C4. The variation between the minimum and maximum value was $250.5 \mathrm{mg} \cdot \mathrm{kg}^{-1}$. In half of the analysed samples the content of iron equalled 34.87 $\mathrm{mg} \cdot \mathrm{kg}^{-1}$. A very high content of Fe in two of the samples (exceeding $100 \mathrm{mg} \cdot \mathrm{kg}^{-1}$ ) caused variability of the results exceeding $112 \%$. Values quoted by Hamad et al. [23] (76 $\left.\mathrm{mg} \cdot \mathrm{kg}^{-1}\right)$, Hamawand et al. [21] $\left(72 \mathrm{mg} \cdot \mathrm{kg}^{-1}\right)$, Cassap [22] (30.8 $\left.\mathrm{mg} \cdot \mathrm{kg}^{-1}\right)$, and Yang [20] (21 $\left.\mathrm{mg} \cdot \mathrm{kg}^{-1}\right)$ remain within the range obtained in the course of the research.

A high bioaccumulation of manganese fulfils an important role in its geochemical circulation. Contamination of the environment with manganese is mainly connected with the metal industry, as well as its emissions bound with coal and liquid fuel combustion [24]. Manganese is introduced into engine oil through the wear of cylinder liners, valves, and shafts. The content of manganese in the analysed samples ranged from 0.41 to $4.27 \mathrm{mg} \cdot \mathrm{kg}^{-1}$ (on average $\left.1.79 \mathrm{mg} \cdot \mathrm{kg}^{-1}\right)$; in the half of analysed samples the content did not exceed $1.63 \mathrm{mg} \cdot \mathrm{kg}^{-1}$. The content of manganese in the analysed samples was characterized by quite a high differentiation factor amounting to almost $60 \%$. The values obtained remain within the range obtained by the other authors (Table 2).

Molybdenum is subjected to high bioaccumulation, thus its concentration in some coal beds, crude oil, and bituminous shale. It is difficult to establish the amount of molybdenum that is introduced directly to biogeochemical circulation. Coal and crude oil combustion introduces into the environment approx. $2000 \mathrm{Mg}$ per annum [24]. Molybdenum in used oil mainly comes from additives used in the oil and it may come as the result of the wear of piston rings [26, 27]. Its average content in the analysed samples was $462.9 \mathrm{mg} \cdot \mathrm{kg}^{-1}$. The maximum content was $689 \mathrm{mg} \cdot \mathrm{kg}^{-1}$, while the minimum was $360 \mathrm{mg} \cdot \mathrm{kg}^{-1}$. The content of Mo in a sample differed from the average value by about $107 \mathrm{mg} \cdot \mathrm{kg}^{-1}$. The variation coefficient reached up to $23 \%$. In this case the content of Mo established in the samples significantly differed from cases noted in the literature. Cassap [22] determined Mo at the 0.38 $\mathrm{mg} \cdot \mathrm{kg}^{-1}$ level, while Hamad et al. [23] measured it at the 6 $\mathrm{mg} \cdot \mathrm{kg}^{-1}$ level. The differences may reflect the fact that used oils analysed by the above-mentioned authors come from passenger cars fuelled with petrol, which influences the wearing character, as well as the composition of engine oil additives.

The age structure of the tractors may be significant, taking into consideration the posed threats. In engines with high mileage the wearing processes runs at a much higher intensity level, therefore the content of elements typical for wearing processes, i.e. $\mathrm{Fe}, \mathrm{Cu}, \mathrm{Pb}, \mathrm{Cr}, \mathrm{Mn}, \mathrm{Ni}$, and $\mathrm{Sn}$ in oils can increase. In order to determine the impact of wearing processes and the age of tractors on the concentration of the elements, the Kruskal-Wallis study was carried out. The test demonstrated that the concentrations of $\mathrm{Fe}$ and $\mathrm{Cr}$ depended significantly on engine mileage. The average content of these elements in oil samples with mileage exceeding $900 \mathrm{~h}$ was significantly higher than in samples with lower mileage. For the remaining elements no statistically significant differences were revealed.

\section{Conclusions}

The only effective way to protect the natural environment from used oil contamination is their collection and controlled utilization. Only appropriate used oil management can guarantee minimal environmental contamination and prevent its irreversible degradation.

The issue of waste management is regulated by a range of legal provisions, although these alone will not suffice for the proper management of such waste. A combination of precise and well-construed legal regulations along with a high ecological awareness of society may only allow for the extent of pro-environmental actions.

On the basis of the conducted research and discussion, we formulated the following conclusions:

1. In none of the analysed used engine oils were mercury and cadmium found. However, based on the literary data the presence of cadmium in used oils from agricultural tractors cannot be ruled out. In the analysed sam- 
ples a high content of $\mathrm{Zn}$ was indicated at the 726-1,389 $\mathrm{mg} \cdot \mathrm{kg}^{-1}$ level. The contents of $\mathrm{Mo}, \mathrm{Fe}$, and $\mathrm{Cu}$ in the analysed samples were also high: Mo 360-689 $\mathrm{mg} \cdot \mathrm{kg}^{-1}$, $\mathrm{Fe}$ 16.5-267 $\mathrm{mg} \cdot \mathrm{kg}^{-1}$, and $\mathrm{Cu}$ 4.63-76.87 $\mathrm{mg} \cdot \mathrm{kg}^{-1}$. The lowest contents of $\mathrm{Ni}, \mathrm{Mn}, \mathrm{Cr}$, and $\mathrm{Pb}$ were stated at the levels of: $\mathrm{Ni} 0.14-0.75 \mathrm{mg} \cdot \mathrm{kg}^{-1}, \mathrm{Mn} 0.41-4.27$ $\mathrm{mg} \cdot \mathrm{kg}^{-1}, \mathrm{Cr}$ 0.36-10.66 $\mathrm{mg} \cdot \mathrm{kg}^{-1}$, and $\mathrm{Pb} 0.9-13.71$ $\mathrm{mg} \cdot \mathrm{kg}^{-1}$.

2. The concentrations of metals that are introduced into oils along with refining additives ( $\mathrm{Zn}, \mathrm{Mo}$ ) are characterized by low variability, while elements present in the oil as a result of engine parts wear ( $\mathrm{Fe}, \mathrm{Cu}, \mathrm{Pb}, \mathrm{Cr}, \mathrm{Mn}, \mathrm{Ni}, \mathrm{Sn}$ ) demonstrate large diversity. Therefore, it is difficult to precisely estimate their amount in the oils, and at the same time determine potential environmental threats.

3. The statistical analysis of the research results indicated statistically significant dependence of the concentrations of iron and chromium in used engine oils from engine mileage. In the case of the other investigated elements no statistically significant dependences were noted according to varying mileage. The age structure of agricultural tractors is significant, taking into consideration the threats posed to the environment. In engines with high mileage, wearing processes run at a much higher intensity level and so the increase of the elements content is typical for wearing processes.

\section{References}

1. ZACHARYASZ P., SIEPAK J., ROSADA J. PetroleumContaminated Soil and Water Analysis and Biodegradation. Pol. J. Environ. Stud., 21, (5), 1467, 2012.

2. SZYSZLAK-BARGLOWICZ J., SLOWIK T., ZAJAC G., PIEKARSKI W. The Content of Heavy Metals in the Drainage Ditches by Communication Routes. Rocznik Ochrona Środowiska, 15, (3), 2309, 2013.

3. MAGIERA J. Re-refining used oil. WN-T, Warszawa, 2006. [In Polish]

4. MAGIERA J., GŁUSZEK A. Used-oils - the Rules of Collection and Ecological Utilization. Pol. J. Environ. Stud., 18, (3A), 230, 2009.

5. The Polish petroleum and natural gas market 2012. Raport Instytutu Nafty i Gazu w Krakowie 7, 2012 [In Polish].

6. PAWLAK Z., URBANIAK W., KALDONSKI T., STYPREKOWSKI M. Energy Conservation Through Recycling of Used Oil. Ecol. Eng., 36, (12), 1761, 2010.

7. Al-OMARI S.B. Used Engine Lubrication Oil as a Renewable Supplementary Fuel for Furnaces. Energ. Convers. Manage., 49, (12), 3648, 2008.

8. DELISTRATY D., STONE A. Dioxins, Metals, and Fish Toxicity in Ash Residue from Space Heaters Burning Used Motor Oil. Chemosphere, 68, (5), 907, 2007.

9. FUENTES M.J., FONT R., GÓMEZ-RICO M.F., MARTÍN-GULLÓN I. Pyrolysis and Combustion of Waste Lubricant Oil from Diesel Cars: Decomposition and Pollutants. J. Anal. Appl. Pyrolysis., 79, (1-2), 215, 2007.

10. MAŁACHOWSKA-JUTSZ A., RUDEK J., JANOSZ W. The Effect of Ribwort (Plantago Lanceolata) and its Myrorrhizas on the Growth of Microflora in Soil Contaminated with Used Engine Oil. Arch. Environ. Prot., 37, (1), 99, 2011.
11. NWADINIGWE A.O., ONYEIDU E.G. Bioremediation of Crude Oil-Polluted Soil Using Bacteria and Poultry Manure Monitored through Soybean Productivity. Pol. J. Environ. Stud., 21, (1), 171, 2012.

12. AUCÉLIO R.Q., de SOUZA R.M., de CAMPOS R.C., MIEKELEY N., da SILVEIRA C.L.P. The Determination of Trace Metals in Lubricating Oils by Atomic Spectrometry. Spectrochim. Acta B. 62, (9), 952, 2007.

13. CARBALlO S., TERÁN J., SOTO R.M., CARLOSENA A., ANDRADE J.M., PRADA D. Green Approaches to Determine Metals in Lubricating Oils by Electrothermal Atomic Absorption Spectrometry (ETAAS). Microchem. J., 108, 74, 2013.

14. KUOKKANEN T., PERÄMÄKI P., VÄLIMÄKI I., RÖNKKÖMÄKI H. Determination of Heavy Metals in Waste Lubricating Oils by Inductively Coupled Plasma Optical Emission Spectrometry. Int. J. Environ. An. Ch., 81, (2), 89, 2001

15. VÄHÄOJA P., VÄLIMÄKI I., ROPPOLA K., KUOKKANEN T., LAHDELMA S. Wear Metal Analysis of Oils. Crit. Rev. Anal. Chem., 38, (2), 67, 2008.

16. LÜTZENKIRCHEN-HECHT D., MÜLLER L., HOFFMANN L., WAGNER R. Analysis of Engine Motor Oils by $\mathrm{X}$-ray Absorption and X-ray Fluorescence Spectroscopies. X-Ray Spectrom, 43, (4), 221, 2014.

17. POUZAR M., CERNOHORSKY T., KREJCOVA A. Determination of Metals in Lubricating Oils by X-ray Fluorescence Spectrometry. Talanta, 54, (5), 829, 2001.

18. SÁGI R., MISKOLCZI N., BARTHA L., HALMOS P. Elemental Analysis of Engine Oils Using Energy Dispersive X-ray Fluorescence Spectroscopy (EDXRFS) and Inductively Coupled Plasma Atomic Emission Spectroscopy (ICP-AES). Pet. Coal., 5, (1), 1, 2008.

19. SIMBOLON S. Determination of Wear Metals in Lubricating Oil by X-Ray Fluorescence Analysis. At. Indones., 2,2 (2), 55, 1996.

20. YANG Z., HOU X., JONES B.T. Determination of Wear Metals in Engine Oil by Mild Acid Digestion And Energy Dispersive X-ray Fluorescence Spectrometry Using Solid Phase Extraction Disks. Talanta, 59, (4), 673, 2003.

21. HAMAWAND I., YUSAF T., RAFAT S. Recycling of Waste Engine Oils Using a New Washing Agent. Energies, 6, 1023, 2013.

22. CASSAP M. The analysis of used lubrication oils by inductively coupled plasma spectrometry for predictive maintenance. Spectroscopy Europe, 20, (1), 17, 2008.

23. HAMAD A., AL-ZUBAIDYA E., FAYED M.E. Used lubricating oil recycling using hydrocarbon solvents. J. Environ. Manage., 74, 153, 2005.

24. KABATA-PENDIAS A., PENDIAS H. Biogeochemistry of trace elements. PWN - Polish Scientific Publishers, Warszawa 1999 [In Polish].

25. KLOJZY-KARCZMARCZYK B. Analysis of Long-term Research on Mercury Content in the Soils in the Immediate Surroundings of the Southern Ring Road of Krakow. Rocznik Ochrona Środowiska, 15, (2), 1069, 2013 [In Polish].

26. NWOSU F.O., OLU-OWOLABI B.I., ADEBOWALE K.O., LEKE L. Comparative Investigation of Wear Metals in Virgin and Used Lubricant Oils. Terrestrial and Aquatic Environmental Toxicology, 2, (1), 38, 2008.

27. PALKENDO J.A., KOVACH J., BETTS T.A. Determination of Wear Metals in Used Motor Oil by Flame Atomic Absorption Spectroscopy. J. Chem. Educ., 91, (4), 579, 2014.

28. RAUCKYTE T., HARGREAVES D.J., PAWLAK Z. Determination of Heavy Metals and Volatile Aromatic Compounds in Used Engine Oils and Sludges. Fuel, 85, (4), 481, 2006. 
